\title{
Analisis Temperatur Terhadap Perpindahan Panas Pada Sistem Pendingin
}

\author{
Erlina Lazahimu ${ }^{1 *}$, La Ode Safiuddin ${ }^{2)}$, La Hasanudin ${ }^{3)}$ \\ 1)* Mahasiswa Jurusan Pendidikan Fisika FKIP UHO, Kendari, Sulawesi Tenggara, Indonesia 93232 \\ ${ }^{2)}$ Dosen Jurusan Pendidikan Fisika FKIP UHO, Kendari, Sulawesi Tenggara, Indonesia 93232 \\ ${ }^{3)}$ Dosen Jurusan Teknik Mesin FT UHO, Kendari, Sulawesi Tenggara, Indonesia 93232 \\ *Koresponden Email: erlinalazahimu99@gmail.com
}

\begin{abstract}
This study aims to: (1) determine the heat transfer process of the room area; (2) to determine the effect of sensible heat load on the performance of air conditioner / AC. This study used an experimental method to obtain data on the temperature of the external coolant load, the load on the inner cooler, the area of the room and the surface area data for each cooling load. The results of this study indicate that: the heat load greatly affects the performance of the air conditioner $(A C)$ in producing a comfortable temperature in the room, such as in the meeting room of the BNN Province of SULTRA using 2 PK AC capacity with a total cooling load of $34,979 \mathrm{Btu} / \mathrm{hr}$ or $8,744.75 \mathrm{kcal}$, so that you have to add an AC unit with a minimum capacity of $2 P K$ to obtain the calorific value that can be moved by the $A C(Q 1)$ is greater than the heat load generated by the room (Q2), which is 36,000 Btu / hr > 34,979 Btu/ hr or 9,000 kcal> 8,744.75 kcal so that comfortable conditions will be obtained.
\end{abstract}

Keywords: Temperature; Cooling Load; Heat Transfer; Air Conditioner (AC)

Abstrak: Penelitian ini bertujuan untuk : (1) mengetahui proses perpindahan panas terhadap luas ruangan; (2) mengetahui pengaruh beban kalor sensibel terhadap kinerja air conditioner/AC. Penelitian ini menggunakan metode eksperimen untuk memperoleh data suhu beban pendingin luar, beban pendingin dalam, luas ruangan dan data luas permukaan setiap beban pendingin. Hasil penelitian ini menunjukkan bahwa : beban kalor sangat mempengaruhi kinerja air conditioner (AC) dalam menghasilkan suhu nyaman dalam ruangan, seperti pada ruang rapat BNN Provinsi SULTRA menggunakan kapasitas AC 2 PK dengan beban pendingin total sebesar $34.979 \mathrm{Btu} / \mathrm{hr}$ atau 8.744,75 kcal, sehingga harus melakukan penambahan unit AC dengan kapasitas minimal 2 PK untuk memperoleh nilai kalor yang dapat dipindahkan $\mathrm{AC}\left(\mathrm{Q}_{1}\right)$ lebih besar dari beban kalor yang dihasilkan ruangan $\left(\mathrm{Q}_{2}\right)$ yaitu $36.000 \mathrm{Btu} / \mathrm{hr}>34.979 \mathrm{Btu} / \mathrm{hr}$ atau $9.000 \mathrm{kcal}>8.744,75 \mathrm{kcal}$ sehingga akan diperoleh kondisi yang nyaman.

Kata Kunci: Temperatur; Beban Pendingin; Perpindahan Panas; Air Conditioner (AC)

\section{PENDAHULUAN}

Refrigeran adalah liduid atau cairan pendingin yang digunakan dalam sistem pengkondisian udara. Refrigerasi adalah pengeluaran kalor dari suatu ruangan dan kemudian mempertahankan keadaannya sedemikian rupa sehingga temperaturnya lebih rendah dari temperatur lingkungannya. Refrigerasi merupakan terapan dari teori perpindahan kalor dan termodinamika, pada dasarnya prinsip kerja Air Conditioner (AC) sama dengan refrigerasi, namun Air Conditioner (AC) tidak berfungsi sebagai pendingin saja, tetapi harus dapat menghasilkan udara nyaman. Hal ini dilakukan dengan jalan pengontrolan terhadap kondisi udara yang meliputi suhu, kelembaban dan gerakan udara (Alfons, 2013). Berdasarkan penelitian yang dilakukan oleh Zuberi pada tahun 2016 tentang pembuatan dan pengujian alat uji prestasi sistem pengkondisian udara (air conditioning) Jenis Split. Untuk hasil pengujian untuk nilai COP, semakin meningkat seiring beban yang semakin besar. Untuk nilai konsumsi energi semakin tinggi beban maka nilai konsumsi energi semakin menurun dan untuk hasil pada EER semakin tinggi beban maka nilai EER cendrung semakin kecil karena seiring besarnya beban dan temperatur pengujian. Selanjutnya penelitian yang dilakukan oleh Zein Muhammad Zein pada tahun 2019 tentang analisa sistem pendingin untuk 
kenyamanan ruangan pada industri garmen. Air Conditioner (AC) yang terpasang pada industri Garmen kapasitasnya tidak sesuai dengan beban kalor yang ditimbulkan selama pekerjaan berlangsung. Suatu ruangan yang menggunakan pengkodisian udara selain mengetahui hal-hal tersebut juga harus mengetahui bagaimana beban internal dan eksternal dari suatu pengkondisian udara yang menghasilkan panas dan mengakibatkan kenaikan suhu di ruangan tersebut yang mempengaruhi kinerja pengkondisian udara.

Setiap bangunan atau ruangan selain mempunyai kondisi beban pendingin puncak juga mempunyai beban total pendingin ruangan, yang biasanya berubah-ubah setiap jamnya. Berdasarkan hal tersebut, suatu gedung atau ruangan yang akan dikondisikan dengan memasang sistem tata udara maka perlu diketahui terlebih dahulu beban maksimum yang ada dan harus ditanggulangi dengan tepat agar dapat dipakai peralatan yang sesuai untuk dipasang. Sehingga, tidak terjadi pemborosan energi dan biaya, serta kemungkinan kurangnya kapasitas mesin yang menyebabkan tidak tercapainya kondisi yang diinginkan. Untuk mengatasi hal tersebut diperlukan perhitungan besaran beban yang tepat pada sistem pengkondisian udara dan menentukan beban yang diterima oleh mesin pendingin (Subedjo, 2011). Semakin banyak beban suatu ruangan maka suhu di ruangan tersebut juga semakin meningkat, suhu inilah yang mempengaruhi kinerja sistem pendingin.

\section{METODE}

1. Waktu dan Tempat Penelitian

Penelitian ini dilaksanakan pada bulan Februari 2019 sampai selesai bertempat di ruang rapat kantor badan narkotika nasional provinsi sulawesi tenggara.

2. Prosedur Penelitian

a. Bagan Alir Prosedur Penelitian

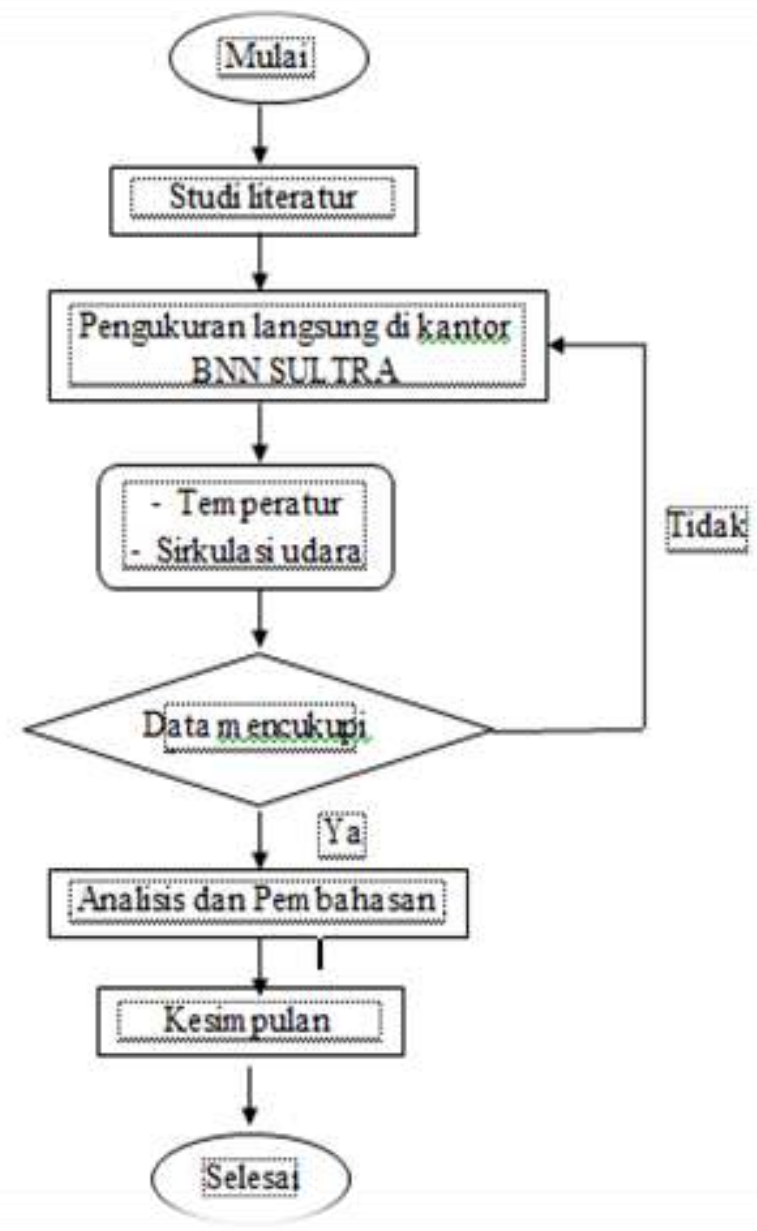

Gambar 1. Diagram alir prosedur penelitian 
b. Analisis Data

1) Beban Pendingin Luar

a) Beban kalor melalui kaca

$$
Q=\left[o, 4 a_{g}\left(a_{s d}+t_{s d}+r_{g} s d+0,4 a_{g} r_{s d}\right)\right] \frac{R}{0,88} \times A
$$

b) Beban kalor melalui dinding

$$
Q=A \cdot U \cdot \Delta t
$$

c) Beban kalor melalui langit-langit

$$
Q=A \cdot U \cdot \Delta t
$$

d) Beban kalor melalui lantai

$$
Q=A \cdot U \cdot \Delta t
$$

e) Beban kalor melalui infiltrasi ruangan

$$
Q=c f m \cdot \Delta t \cdot 1,08
$$

2) Beban pendingin dalam
a) Penghuni $\rightarrow$ asumsi duduk santai

$Q$ pria $=\sum$ orang $\times$ beban orang beraktifitas

$Q$ wanita $=\sum$ orang $\times$ beban orang beraktifitas $\times 0,85$

b) Lampu -> beban sensibel lampu Flourecent (neon) $Q=$ total watt $\times 1,25 \times 3,4$

c) Komputer $Q=$ total watt $\times 3,4$

d) $\mathrm{LCD}$

$$
Q=\text { total watt } \times 3,4
$$

3) Beban Transmisi Panas Ruangan

$$
Q=U A\left(t_{0}-t_{1}\right)
$$

\section{HASIL PENELITIAN}

1. Data yang diperoleh

Luas Ruangan $\quad=8,25 \times 7,1 \mathrm{~m}^{2}$

Tinggi Ruangan $\quad=3,3 \mathrm{~m}$

Luas Kaca 1 (9 buah) $=1,7 \times 0,8 \mathrm{~m}^{2}$ atau $14,64 \mathrm{ft}^{2}$
Luas Kaca 2 (2 buah) $=2,2 \times 0,9 \mathrm{~m}^{2}$ atau 21,313 $\mathrm{ft}^{2}$ Luas Kaca 3 (6 buah) $=1,7 \times 0,5 \mathrm{~m}^{2}$ atau 9,149 $\mathrm{ft}^{2}$ Luas Kaca 4 (2 buah $)=2 \times 1 \mathrm{~m}^{2}$ atau $3,4 \mathrm{ft}^{2}$ Luas Kaca 5 ( 2 buah) $=2 \times 0,6 \mathrm{~m}^{2}$ atau $1,2 \mathrm{ft}^{2}$ Luas Kaca 6 (4 buah) $=0,6 \times 0,5 \mathrm{~m}^{2}$ atau $0,3 \mathrm{ft}^{2}$ Luas Kaca 7 (4 buah) $=1 \times 0,5 \mathrm{~m}^{2}$ atau $0,5 \mathrm{ft}^{2}$ Luas Dinding Belakang = 7,35 x 3,3 $\mathrm{m}^{2}$ atau 261,08 $\mathrm{ft}^{2}$ Luas Dinding Depan $=8,25 \times 3,3 \mathrm{~m}^{2}$ atau 293,05 $\mathrm{ft}^{2}$ Luas Dinding Kiri $\quad=7,1 \times 3,3 \mathrm{~m}^{2}$ atau $252,2 \mathrm{ft}^{2}$ Luas Dinding Kanan $=6 \times 3,3 \mathrm{~m}^{2}$ atau $213,13 \mathrm{ft}^{2}$ Luas Langit-langit $\quad=8,25 \times 7,1 \mathrm{~m}^{2}$ atau $630,5 \mathrm{ft}^{2}$ Luas Lantai $=8,25 \times 7,1 \mathrm{~m}^{2}$ atau $630,5 \mathrm{ft}^{2}$ Penghuni (menghadiri rapat $)=30(20$ pria dan 10 wanita $)$ 10 Buah Lampu neon (21 watt) 1 Buah Komputer (100 watt)

1 Buah LCD ( 250 watt)

a) Beban Transmisi Panas Ruangan

Beban transmisi panas yang terjadi pada ruangan yaitu melalui kaca, dinding, lantai dan langit-langit.

1) Transmisi Panas Melalui Kaca (pukul 08:00)

$$
\begin{aligned}
Q=U A & \left(t_{0}-t_{1}\right) \\
\text { Dik }: A & =14,693 \mathrm{ft} \\
\mathrm{U} & =0,8 \mathrm{~W} / \mathrm{m}^{2}{ }^{0} \mathrm{C} \\
\Delta \mathrm{t} & =1{ }^{0} \mathrm{C}
\end{aligned}
$$

Dit : Q Kaca $1=\ldots$ ?

Penyelesaian :

$$
\begin{aligned}
& Q=U A\left(t_{0}-t_{1}\right) \\
& Q=14,693 \cdot 0,8 \cdot 1 \\
& \mathrm{Q}=11,711 \mathrm{Btu} / \mathrm{hr}
\end{aligned}
$$

Tabel 1. Perhitungan beban transmisi panas melalui kaca 1 pada pukul 08:00 s/d 16:00

\begin{tabular}{cccccccc}
\hline Pukul & $\mathbf{U}$ & $\mathbf{A}$ & $\mathbf{t}_{\mathbf{0}}$ & $\mathbf{t}_{\mathbf{1}}$ & $\Delta \mathbf{T}$ & $\mathbf{Q}(\mathbf{b t u} / \mathbf{h})$ & Q kcal \\
\hline $8: 00$ & 0,8 & 14,639 & 26 & 25 & 1 & $\mathbf{1 1 , 7 1 1}$ & $\mathbf{2 , 9 2 7}$ \\
\hline $10: 00$ & 0,8 & 14,639 & 26,1 & 25 & 1,1 & $\mathbf{1 2 , 8 8 2}$ & $\mathbf{3 , 2 2}$ \\
\hline $12: 00$ & 0,8 & 14,639 & 26,3 & 25 & 1,3 & $\mathbf{1 5 , 2 2 4}$ & $\mathbf{3 , 8 0 6}$ \\
\hline $14: 00$ & 0,8 & 14,639 & 26,2 & 25 & 1,2 & $\mathbf{1 4 , 0 5 3}$ & $\mathbf{3 , 5 1 3}$ \\
\hline $16: 00$ & 0,8 & 14,639 & 25,9 & 25 & 0,9 & $\mathbf{1 0 , 5 4}$ & $\mathbf{2 , 6 3 5}$ \\
\hline \multicolumn{7}{c}{ Total Transmisi Panas Melalui Kaca 1 } & $\mathbf{6 4 , 4 1 1}$ \\
\hline
\end{tabular}


Tabel 2. Perhitungan beban transmisi panas melalui kaca 2 pada pukul 08:00 s/d 16:00

\begin{tabular}{|c|c|c|c|c|c|c|c|}
\hline Pukul & $\mathbf{U}$ & $\mathbf{A}$ & $\mathbf{t}_{0}$ & $t_{1}$ & $\Delta \mathbf{T}$ & $\mathbf{Q}(\mathbf{b t u} / \mathbf{h})$ & Q kcal \\
\hline 8:00 & 0,8 & 21,3127 & 26,03 & 25 & 1,03 & 17,561 & 4,39 \\
\hline 10:00 & 0,8 & 21,3127 & 26,07 & 25 & 1,07 & 18,243 & 4,56 \\
\hline 12:00 & 0,8 & 21,3127 & 26,38 & 25 & 1,38 & 23,529 & $\mathbf{5 , 8 8 2}$ \\
\hline 14:00 & 0,8 & 21,3127 & 26,25 & 25 & 1,25 & 21,312 & 5,328 \\
\hline 16:00 & 0,8 & 21,3127 & 25,97 & 25 & 0,97 & 16,538 & 4,134 \\
\hline \multicolumn{6}{|c|}{ Total Transmisi Panas Melalui Kaca 2} & 97,186 & 24,296 \\
\hline
\end{tabular}

Tabel 3. Perhitungan beban transmisi panas melalui kaca 3 pada pukul 08:00 s/d 16:00

\begin{tabular}{cccccccc}
\hline Pukul & $\mathbf{U}$ & $\mathbf{A}$ & $\mathbf{t}_{\mathbf{0}}$ & $\mathbf{t}_{\mathbf{1}}$ & $\Delta \mathbf{T}$ & $\mathbf{Q}(\mathbf{b t u} / \mathbf{h})$ & $\mathbf{Q}$ kcal \\
\hline $08: 00$ & 0,8 & 9,1494 & 30,08 & 25 & 5,08 & $\mathbf{3 7 , 1 8 3}$ & $\mathbf{9 , 2 9 5}$ \\
\hline $10: 00$ & 0,8 & 9,1494 & 29,9 & 25 & 4,9 & $\mathbf{3 5 , 8 6 5}$ & $\mathbf{8 , 9 6 6}$ \\
\hline $12: 00$ & 0,8 & 9,1494 & 30,92 & 25 & 5,92 & $\mathbf{4 3 , 3 3 1}$ & $\mathbf{1 0 , 8 3 2}$ \\
\hline $14: 00$ & 0,8 & 9,1494 & 30,21 & 25 & 5,21 & $\mathbf{3 8 , 1 3 4}$ & $\mathbf{9 , 5 3 3}$ \\
\hline $16: 00$ & 0,8 & 9,1494 & 29,32 & 25 & 4,32 & $\mathbf{3 1 , 6 2}$ & $\mathbf{7 , 9 0 5}$ \\
\hline \multicolumn{6}{c}{ Total Transmisi Panas Melalui Kaca 3 } & $\mathbf{1 8 6 , 1 3 5}$ & $\mathbf{4 6 , 5 3 3}$ \\
\hline
\end{tabular}

Tabel 4. Perhitungan beban transmisi panas melalui kaca 4 pada pukul 08:00 s/d 16:00

\begin{tabular}{|c|c|c|c|c|c|c|c|}
\hline Pukul & $\mathbf{U}$ & $\mathbf{A}$ & $\mathbf{t}_{0}$ & $\mathbf{t}_{1}$ & $\Delta \mathbf{T}$ & $\mathbf{Q}(\mathbf{b t u} / \mathbf{h})$ & Q kcal \\
\hline 8:00 & 0,8 & 21,528 & 29,97 & 25 & 4,97 & 85,595 & 21,398 \\
\hline $10: 00$ & 0,8 & 21,528 & 29,82 & 25 & 4,82 & 83,012 & 20,753 \\
\hline $12: 00$ & 0,8 & 21,528 & 30,89 & 25 & 5,89 & 101,44 & 25,36 \\
\hline 14:00 & 0,8 & 21,528 & 30,17 & 25 & 5,17 & 89,039 & 22,259 \\
\hline $16: 00$ & 0,8 & 21,528 & 29,12 & 25 & 4,12 & 70,956 & 17,739 \\
\hline \multicolumn{6}{|c|}{ Total Transmisi Panas Melalui Kaca 4} & 430,043 & 107,51 \\
\hline
\end{tabular}

Tabel 5. Perhitungan beban transmisi panas melalui kaca 5 pada pukul 08:00 s/d $16: 00$

\begin{tabular}{|c|c|c|c|c|c|c|c|}
\hline Pukul & $\mathbf{U}$ & A & $\mathbf{t}_{0}$ & $\mathbf{t}_{1}$ & $\Delta \mathbf{T}$ & Q (btu/h) & Q kcal \\
\hline $8: 00$ & 0,8 & 12,9168 & 29,71 & 25 & 4,71 & 48,67 & 12,167 \\
\hline $10: 00$ & 0,8 & 12,9168 & 29,69 & 25 & 4,69 & 48,463 & 12,115 \\
\hline $12: 00$ & 0,8 & 12,9168 & 30,86 & 25 & 5,86 & $\mathbf{6 0 , 5 5 4}$ & 15,138 \\
\hline 14:00 & 0,8 & 12,9168 & 30,09 & 25 & 5,09 & 52,597 & 13,149 \\
\hline $16: 00$ & 0,8 & 12,9168 & 29,15 & 25 & 4,15 & 42,883 & $\mathbf{1 0 , 7 2}$ \\
\hline \multicolumn{6}{|c|}{ Total Transmisi Panas Melalui Kaca 5} & 253,169 & 63,292 \\
\hline
\end{tabular}

Tabel 6. Perhitungan beban transmisi panas melalui kaca 6 pada pukul 08:00 s/d 16:00

\begin{tabular}{|c|c|c|c|c|c|c|c|}
\hline Pukul & $\mathbf{U}$ & A & $\mathbf{t}_{0}$ & $t_{1}$ & $\Delta \mathbf{T}$ & Q (btu/h) & Q kcal \\
\hline $8: 00$ & 0,8 & 3,2292 & 29,42 & 25 & 4,42 & 11,418 & 2,854 \\
\hline 10:00 & 0,8 & 3,2292 & 29,67 & 25 & 4,67 & 12,064 & 3,016 \\
\hline $12: 00$ & 0,8 & 3,2292 & 30,73 & 25 & 5,73 & 14,802 & 3,7 \\
\hline 14:00 & 0,8 & 3,2292 & 30,1 & 25 & 5,1 & 13,175 & 3,293 \\
\hline 16:00 & 0,8 & 3,2292 & 29,13 & 25 & 4,13 & 10,669 & 2,667 \\
\hline \multicolumn{6}{|c|}{ isi Panas Melalu } & 62,129 & 15,532 \\
\hline
\end{tabular}

Tabel 7. Perhitungan beban transmisi panas melalui kaca 7 pada pukul 08:00 s/d 16:00

\begin{tabular}{|c|c|c|c|c|c|c|c|}
\hline Pukul & $\mathbf{U}$ & A & $\mathbf{t}_{0}$ & $\mathbf{t}_{1}$ & $\Delta \mathbf{T}$ & $\mathbf{Q}(\mathbf{b t u} / \mathbf{h})$ & Q kcal \\
\hline $8: 00$ & 0,8 & 5,382 & 29,42 & 25 & 4,42 & 19,03 & 4,757 \\
\hline $10: 00$ & 0,8 & 5,382 & 29,67 & 25 & 4,67 & 20,107 & 5,026 \\
\hline 12:00 & 0,8 & 5,382 & 30,73 & 25 & 5,73 & 24,671 & 6,167 \\
\hline 14:00 & 0,8 & 5,382 & 30,1 & 25 & 5,1 & 21,958 & 5,489 \\
\hline $16: 00$ & 0,8 & 5,382 & 29,13 & 25 & 4,13 & $\mathbf{1 7 , 7 8 2}$ & 4,445 \\
\hline \multicolumn{6}{|c|}{ Total Transmisi Panas Melalui Kaca 7} & 103,55 & $\mathbf{2 5 , 8 8 7}$ \\
\hline
\end{tabular}


Grafik perhitungan beban transmisi panas melalui kaca 1 s/d 7 pada pukul 08:00 s/d 16:00.

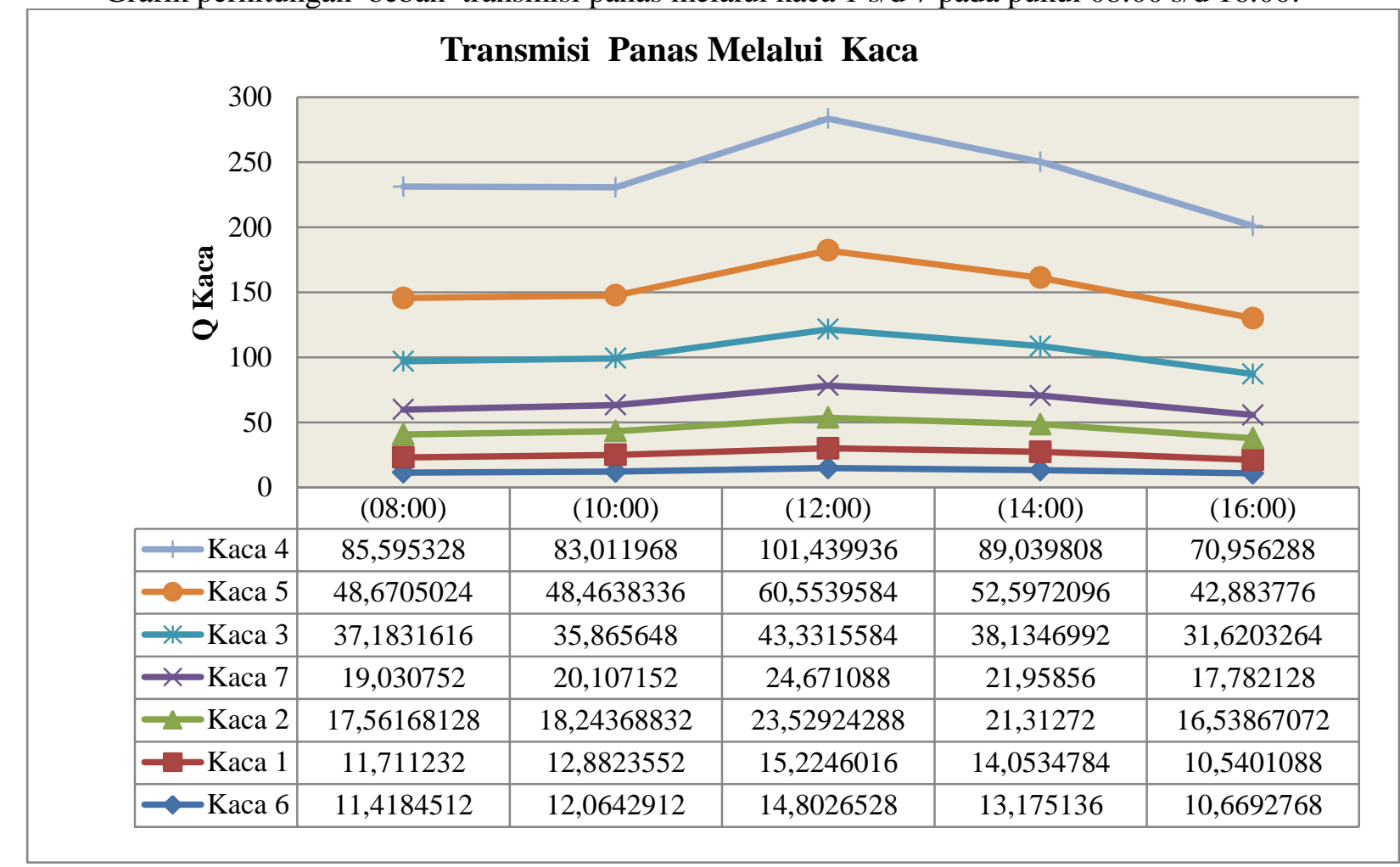

Gambar 2. Beban transmisi panas melalui kaca 1 s/d 6 pada pukul 08:00 s/d 16:00

2) Transmisi panas melalui dinding

Tabel 8. Perhitungan beban transmisi panas melalui dinding belakang pada pukul 08:00 s/d 16:00

\begin{tabular}{cccccccc}
\hline Pukul & $\mathbf{U}$ & $\mathbf{A}$ & $\mathbf{t}_{\mathbf{0}}$ & $\mathbf{t}_{\mathbf{1}}$ & $\Delta \mathbf{T}$ & $\mathbf{Q}(\mathbf{b t u} / \mathbf{h})$ & $\mathbf{Q}$ kcal \\
\hline $8: 00$ & 0,8 & 261,08 & 26,6 & 25 & 1,6 & $\mathbf{3 3 4 , 1 8 3}$ & $\mathbf{8 3 , 5 4 5}$ \\
\hline $10: 00$ & 0,8 & 261,08 & 26,92 & 25 & 1,92 & $\mathbf{4 0 1 , 0 2}$ & $\mathbf{1 0 0 , 2 5 5}$ \\
\hline $12: 00$ & 0,8 & 261,08 & 27,13 & 25 & 2,13 & $\mathbf{4 4 4 , 8 8 2}$ & $\mathbf{1 1 1 , 2 2}$ \\
\hline $14: 00$ & 0,8 & 261,08 & 27,19 & 25 & 2,19 & $\mathbf{4 5 7 , 4 1 4}$ & $\mathbf{1 1 4 , 3 5 3}$ \\
\hline $16: 00$ & 0,8 & 261,08 & 26,91 & 25 & 1,91 & $\mathbf{3 9 8 , 9 3 1}$ & $\mathbf{9 9 , 7 3 2}$ \\
\hline \multicolumn{6}{c}{ Total Transmisi Panas Melalui Dinding Belakang } & $\mathbf{2 0 3 6 , 4 3}$ & $\mathbf{5 0 9 , 1 0 7}$ \\
\hline
\end{tabular}

Tabel 9. Perhitungan beban transmisi panas melalui dinding depan pada pukul 08:00 s/d 16:00

\begin{tabular}{|c|c|c|c|c|c|c|c|}
\hline Pukul & $\mathbf{U}$ & $\mathbf{A}$ & $\mathbf{t}_{0}$ & $\mathbf{t}_{1}$ & $\Delta \mathbf{T}$ & Q (btu/h) & Q kcal \\
\hline 08:00 & 0,25 & 293,05 & 26,36 & 25 & 1,36 & 99,637 & 24,909 \\
\hline 10:00 & 0,25 & 293,05 & 26,54 & 25 & 1,54 & 112,824 & 28,206 \\
\hline $12: 00$ & 0,25 & 293,05 & 26,81 & 25 & 1,81 & 132,605 & 33,151 \\
\hline $14: 00$ & 0,25 & 293,05 & 26,77 & 25 & 1,77 & 129,675 & 32,418 \\
\hline $16: 00$ & 0,25 & 293,05 & 26,41 & 25 & 1,41 & 103,3 & 25,825 \\
\hline \multicolumn{6}{|c|}{ Total Transmisi Panas Melalui Dinding Depan } & 578,041 & 144,51 \\
\hline
\end{tabular}

Tabel 10. Perhitungan beban transmisi panas melalui dinding kiri pada pukul 08:00 s/d 16:00

\begin{tabular}{cccccccc}
\hline Pukul & $\mathbf{U}$ & $\mathbf{A}$ & $\mathbf{t}_{\mathbf{0}}$ & $\mathbf{t}_{\mathbf{1}}$ & $\Delta \mathbf{T}$ & $\mathbf{Q}($ btu/h) & $\mathbf{Q}$ kcal \\
\hline $08: 00$ & 0,25 & 252,201 & 26 & 25 & 1 & $\mathbf{6 3 , 0 5}$ & $\mathbf{1 5 , 7 6 2}$ \\
\hline $10: 00$ & 0,25 & 252,201 & 26,42 & 25 & 1,42 & $\mathbf{8 9 , 5 3 1}$ & $\mathbf{2 2 , 3 8 2}$ \\
\hline $12: 00$ & 0,25 & 252,201 & 26,64 & 25 & 1,64 & $\mathbf{1 0 3 , 4 0 2}$ & $\mathbf{2 5 , 8 5}$ \\
\hline $14: 00$ & 0,25 & 252,201 & 26,75 & 25 & 1,75 & $\mathbf{1 1 0 , 3 3 8}$ & $\mathbf{2 7 , 5 8 4}$ \\
\hline
\end{tabular}




\begin{tabular}{|c|c|c|c|c|c|c|c|}
\hline $16: 00$ & 0,25 & 252,201 & 26,31 & 25 & 1,31 & 82,595 & 20,648 \\
\hline \multicolumn{6}{|c|}{ Total Transmisi Panas Melalui Dinding Kiri } & 448,917 & 112,229 \\
\hline \multicolumn{8}{|c|}{ Tabel 11. Perhitungan beban transmisi panas melalui dinding kanan pada pukul 08:00 s/d 16:00 } \\
\hline Pukul & $\mathbf{U}$ & $\mathbf{A}$ & $\mathbf{t}_{\mathbf{0}}$ & $\mathbf{t}_{1}$ & $\Delta \mathbf{T}$ & $\mathbf{Q}(\mathbf{b t u} / \mathbf{h})$ & Q kcal \\
\hline 08:00 & 0,8 & 213,13 & 26,67 & 25 & 1,67 & 284,738 & 71,184 \\
\hline 10:00 & 0,8 & 213,13 & 26,65 & 25 & 1,65 & 281,328 & 70,332 \\
\hline $12: 00$ & 0,8 & 213,13 & 26,56 & 25 & 1,56 & 265,983 & 66,495 \\
\hline 14:00 & 0,8 & 213,13 & 26,71 & 25 & 1,71 & 291,558 & 72,889 \\
\hline $16: 00$ & 0,8 & 213,13 & 26,44 & 25 & 1,44 & 245,523 & 61,38 \\
\hline \multicolumn{6}{|c|}{ Total Transmisi Panas Melalui Dinding Kanan } & 1369,13 & 342,282 \\
\hline
\end{tabular}

Grafik perhitungan beban transmisi panas melalui dinding belakang, depan, kiri dan kanan pada pukul 08:00 s/d 16:00.

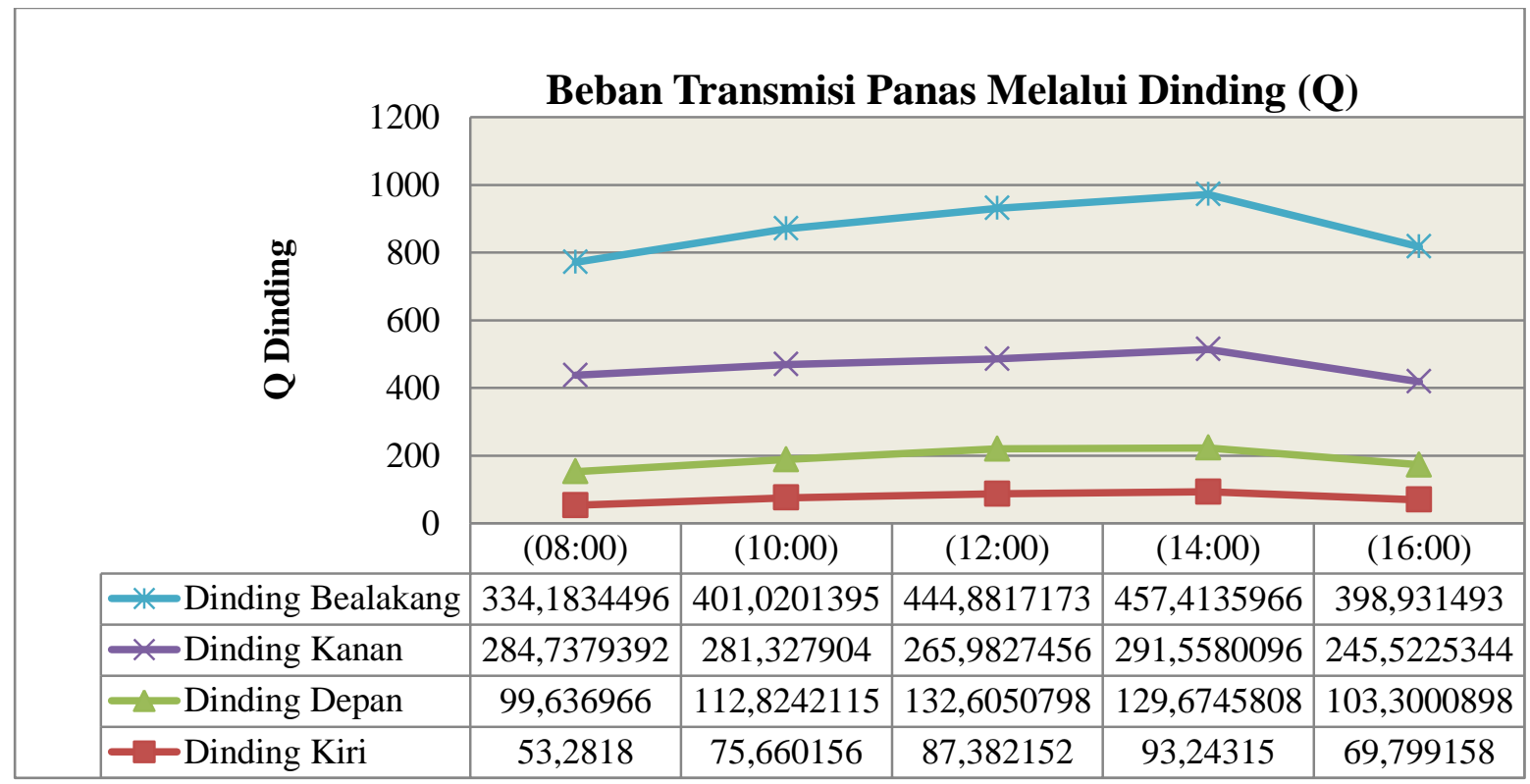

Gambar 3. Beban transmisi panas melalui dinding belakang, depan, kiri dan kanan pada pukul 08:00 s/d 16:00 3) Transmisi panas melalui langit-langit

Tabel 12. Perhitungan beban transmisi panas melalui langit-langit pada pukul 08:00 s/d 16:00

\begin{tabular}{|c|c|c|c|c|c|c|c|}
\hline Pukul & $\mathbf{U}$ & A & $\mathbf{t}_{0}$ & $\mathbf{t}_{1}$ & $\Delta \mathbf{T}$ & $\mathbf{Q}(\mathbf{b t u} / \mathbf{h})$ & Q kcal \\
\hline 08:00 & 0,25 & 630,5 & 27 & 25 & 2 & 315,251 & 78,812 \\
\hline $10: 00$ & 0,25 & 630,5 & 27 & 25 & 2 & 315,251 & 78,812 \\
\hline $12: 00$ & 0,25 & 630,5 & 27,7 & 25 & 2,7 & 425,588 & 106,397 \\
\hline $14: 00$ & 0,25 & 630,5 & 27,8 & 25 & 2,8 & 441,351 & 110,337 \\
\hline $16: 00$ & 0,25 & 630,5 & 27,2 & 25 & 2,2 & 346,776 & 86,694 \\
\hline \multicolumn{6}{|c|}{ Total Transmisi Panas Melalui Langit-langit } & 1844,22 & 461,055 \\
\hline
\end{tabular}

Grafik perhitungan beban transmisi panas melalui langit-langit pada pukul 08:00s/d 16:00. 


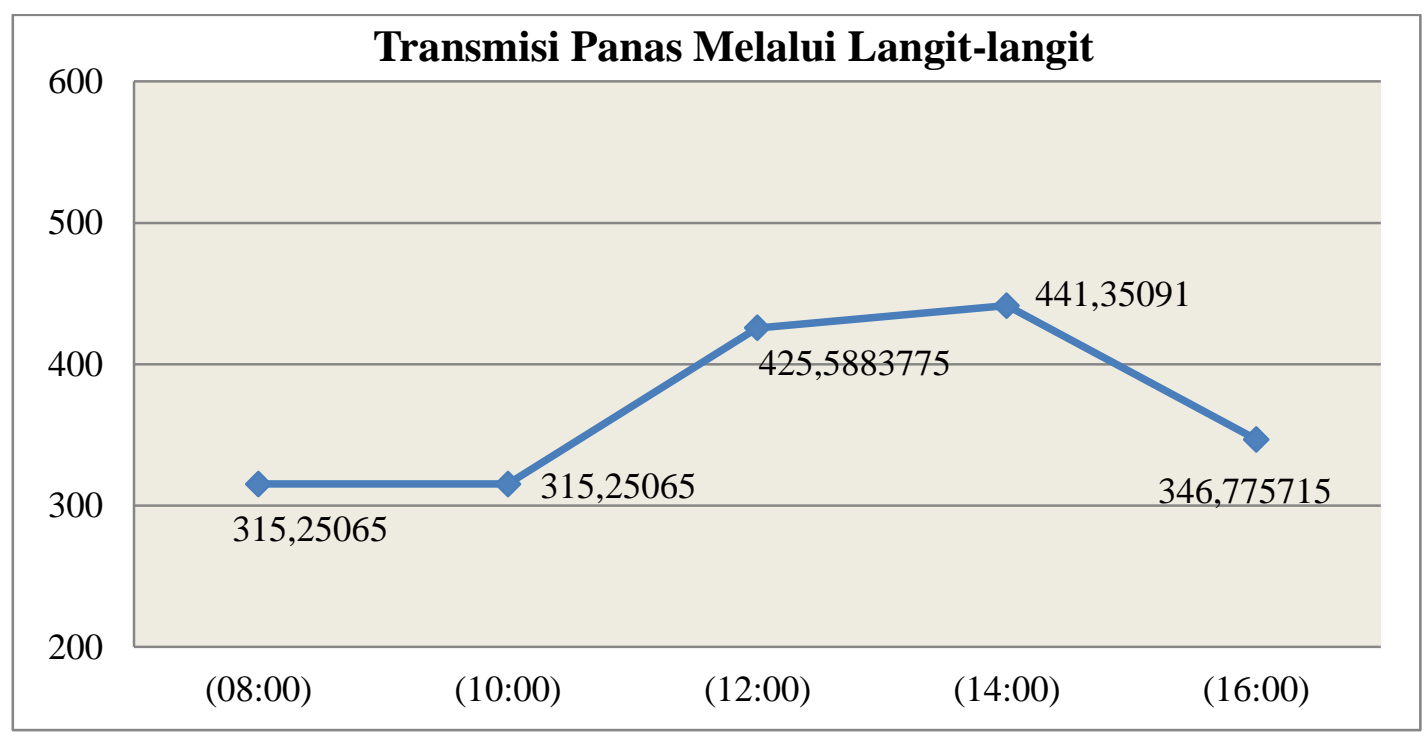

Gambar 4. Beban transmisi panas melalui langit-langit pada pukul 08:00 s/d 16:00

4) Transmisi panas melalui lantai

Tabel 13. Perhitungan beban transmisi panas melalui lantai pada pukul 08:00 s/d 16:00

\begin{tabular}{cccccccc}
\hline Pukul & $\mathbf{U}$ & $\mathbf{A}$ & $\mathbf{t}_{\mathbf{0}}$ & $\mathbf{t}_{\mathbf{1}}$ & $\Delta \mathbf{T}$ & $\mathbf{Q}(\mathbf{b t u} / \mathbf{h})$ & $\mathbf{Q}$ kcal \\
\hline $08: 00$ & 0,58 & 630,501 & 26 & 25 & 1 & $\mathbf{3 6 5 , 6 9 1}$ & $\mathbf{9 1 , 4 2 2}$ \\
\hline $10: 00$ & 0,58 & 630,501 & 26,1 & 25 & 1,1 & $\mathbf{4 0 2 , 2 6}$ & $\mathbf{1 0 0 , 5 6 5}$ \\
\hline $12: 00$ & 0,58 & 630,501 & 26,3 & 25 & 1,3 & $\mathbf{4 7 5 , 3 9 8}$ & $\mathbf{1 1 8 , 8 4 9}$ \\
\hline $14: 00$ & 0,58 & 630,501 & 26,2 & 25 & 1,2 & $\mathbf{4 3 8 , 8 2 9}$ & $\mathbf{1 0 9 , 7 0 7}$ \\
\hline $16: 00$ & 0,58 & 630,501 & 25,9 & 25 & 0,9 & $\mathbf{3 2 9 , 1 2 2}$ & $\mathbf{8 2 , 2 8}$ \\
\hline
\end{tabular}

Grafik perhitungan beban transmisi panas melalui lantai pada pukul 08:00 s/d 16:00.

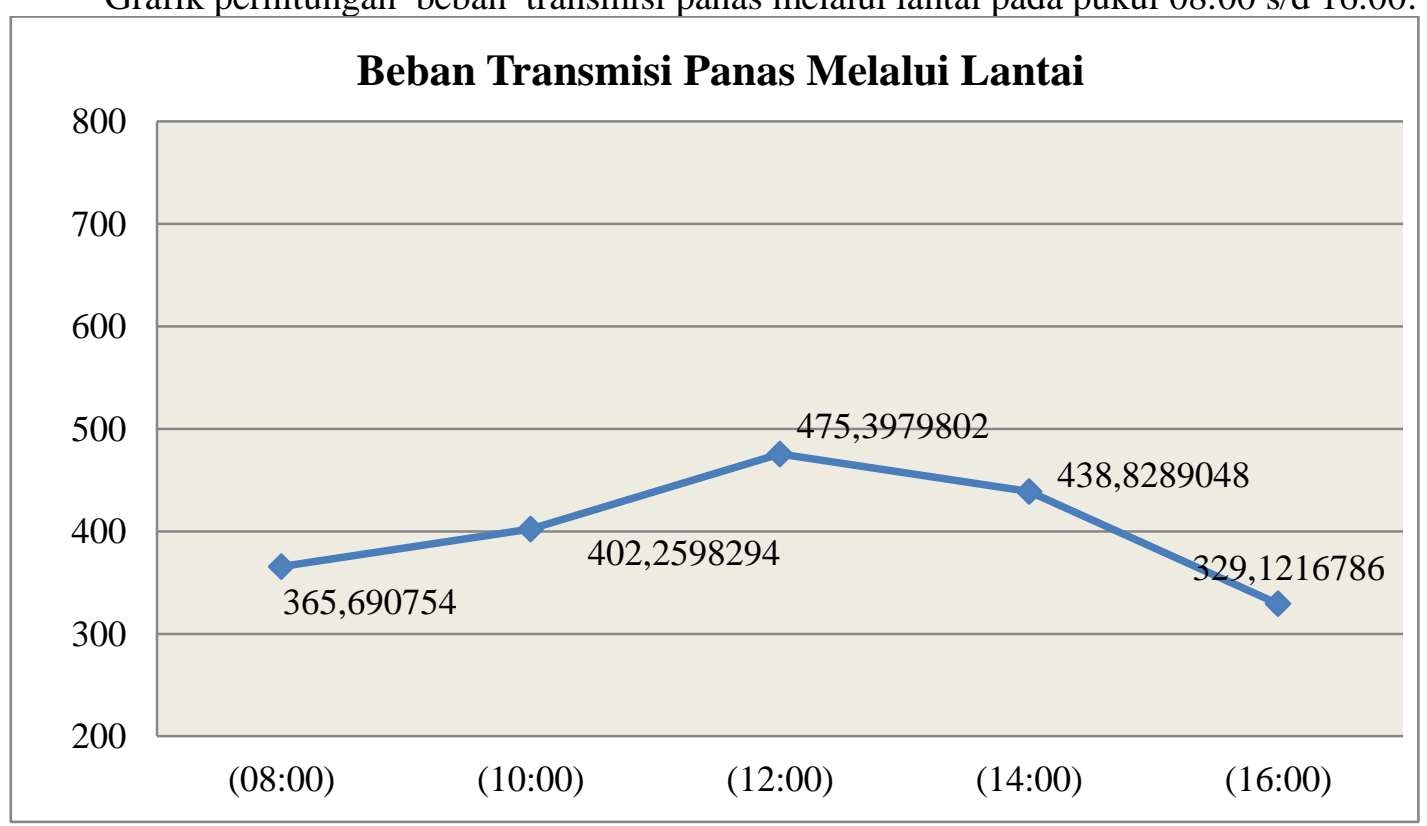

Gambar 5. Beban transmisi panas melalui lantai pada pukul 08:00 s/d 16:00 
b) Perhitungan Total Beban Pendingin Luar dan Dalam

1) Beban Pendingin Luar

a) Melalui Kaca

$Q$ Total Kaca $=Q_{\text {Kaca } 1}+Q_{\text {Kaca } 2}+Q_{\text {Kaca } 3}+Q_{\text {Kaca } 4}+Q_{\text {Kaca } 5}+Q_{\text {Kaca } 6}+Q_{\text {Kaca } 7}$

$Q$ Total Kaca $=850,81+1.173+597+1.403+841+210+1403$

$\mathrm{Q}=5.425 \mathrm{Btu} / \mathrm{hr}$ atau $1.356,25 \mathrm{kcal}$

b) Melalui Dinding

$Q$ Total Dinding $=Q_{\text {Belakang }}+Q_{\text {Depan }}+Q_{\text {Kiri }}+Q_{\text {Kanan }}$

$Q$ Total Dinding $=3.602,92+1.400,05+1.253,44+3.234,42$

$\mathrm{Q}=9.491 \mathrm{Btu} / \mathrm{hr}$ atau $2.372,75 \mathrm{kcal}$

c) Melalui Langit-langit

$\mathrm{Q}=2.412 \mathrm{Btu} / \mathrm{hr}$ atau $603 \mathrm{kcal}$

d) Melalui Lantai

$\mathrm{Q}=7.862 \mathrm{Btu} / \mathrm{hr}$ atau $1.965,5 \mathrm{kcal}$

e) Melalui Infiltrasi

$\mathrm{Q}=1.151 \mathrm{Btu} / \mathrm{hr}$ atau $287,75 \mathrm{kcal}$

Sehingga Beban Total Pendingin Luar adalah :

$Q$ Total Pendingin Luar $=Q$ Kaca $+Q$ Dinding $+Q$ Langit - langit

$+Q$ Lantai $+Q$ Infiltrasi

$Q$ Total Pendingin Luar $=5.425+9.491+2.412+7.862+1.151$

Q Total Pendingin Luar $=26.341 \mathrm{Btu} / \mathrm{Hr}$ atau $6.585,25 \mathrm{kcal}$

2) Beban Pendingin Dalam

$Q$ Total Pendingin Dalam $=Q$ Penghuni Pria $+Q$ Penghuni Wanita +

$$
Q \text { Lampu }+Q \text { Komputer }+Q L C D
$$

$Q$ Total Pendingin Dalam $=4.600+1.955+892,5+850+340$

$\mathrm{Q}$ Total Pendingin Dalam $=8.638 \mathrm{Btu} / \mathrm{Hr}$ atau $2.159,5 \mathrm{kcal}$

3) Total Beban Pendingin

$Q$ Total Pendingin $=Q$ Pendingin Luar $+Q$ Pendingin Dalam

$Q$ Total Pendingin $=26.341+8.638$

$\mathrm{Q}$ Total Pendingin $=34.979 \mathrm{Btu} / \mathrm{H}$ atau $8.744,75 \mathrm{kcal}$

\section{PEMBAHASAN}

Beban Pendingin Merupakan jumlah panas yang dipindahkan oleh suatu sistem pengkondisian udara. Beban pendingin terdiri dari beban pendingin luar (eksternal) dan beban pendingin dalam (internal). Suatu ruangan yang menggunakan sistem pengkondisian udara harus mengetahui terlebih dahulu besarnya kalor yang dapat dipindahkan misalkan $\left(\mathrm{Q}_{1}\right)$ dan memperhitungkan besarnya kalor yang akan dihasilkan baik dari beban pendingin luar maupun beban pendingin dalam misalkan $\left(\mathrm{Q}_{2}\right)$. Salah satu ruangan yang menggunakan sistem pengkondisian udara adalah Ruang Rapat Kantor Badan Narkotika Nasional Provinsi Sulawesi Tenggara. Ruang rapat tersebut menggunakan pengkondisian udara atau $\mathrm{AC}$ dengan kapasitas 2 PK. Beban pendingin luar ruangan terdiri dari beban kalor melalui kaca, dinding, langit-langit, lantai dan infiltrasi. Sedangkan beban pendingin dalam terdiri dari beban kalor penghuni, lampu, computer dan LCD.
Berdasarkan hasil penelitian dan perhitungan total beban kalor pendingin luar diperoleh nilai sebesar 26.341 $\mathrm{Btu} / \mathrm{hr}$ atau $6.585,25 \mathrm{kcal}$. Beban kalor pendingin luar yang cukup besar adalah beban kalor melalui dinding ruangan bagian belakang (timur) sebesar $3.603 \mathrm{Btu} / \mathrm{hr}$ atau 900,75 kcal karena terkena sinar matahari langsung. Sedangkan perhitungan total beban kalor pendingin dalam diperoleh nilai sebesar $8.638 \mathrm{Btu} / \mathrm{hr}$ atau 2.159,5 kcal. Beban kalor pendingin dalam yang cukup besar adalah beban penghuni sebesar $6.555 \mathrm{Btu} / \mathrm{hr}$ atau $1.638,75 \mathrm{kcal}$ karena semakin banyak penghuni maka akan semakin banyak kalor yang dihasilkan.

Berdasarkan perhitungan total beban pendingin baik beban kalor pendingin luar dan beban kalor pendingin dalam diperoleh nilai sebesar $34.979 \mathrm{Btu} / \mathrm{hr}$ atau 8.744,75 kcal. Diketahui bahwa di ruang rapat tersebut menggunakan kapasitas pengkondisian udara atau AC 2 PK dengan luas ruangan $8,25 \times 7,1 \mathrm{~m}^{2}$, secara teori 
kapasitas AC 2 PK dapat memindahkan panas sebesar 18.000 Btu/hr saja atau setara dengan $4.500 \mathrm{kcal}$, sehingga nilai kalor yang dihasilkan lebih besar daripada kalor yang dapat dihilangkan yaitu $\mathrm{Q}_{1}=18.000 \mathrm{Btu} / \mathrm{hr}<\mathrm{Q}_{2}=34.979$ $\mathrm{Btu} / \mathrm{hr}$ atau $4.500 \mathrm{kcal}<8.744,75 \mathrm{kcal}$. Oleh karena itu, perlu adanya penambahan sistem pengkondisian udara atau AC dengan kapasitas minimal 2 PK sehingga akan diperoleh nilai kalor yang dipindahkan lebih besar dari kalor yang dihasilkan yaitu $\mathrm{Q}_{1}=36.000 \mathrm{Btu} / \mathrm{hr}>\mathrm{Q}_{2}=$ 34.979 Btu/hr atau $9.000 \mathrm{kcal}>8.744,75 \mathrm{kcal}$.

Berdasarkan perhitungan beban transmisi panas melalui kaca, dinding, langit-langit dan lantai diperoleh nilai transmisi panas sebesar $9416 \mathrm{Btu} / \mathrm{hr}$ atau $2.354 \mathrm{kcal}$. Beban transmisi yang cukup besar adalah beban transmisi melalui dinding sebesar $4363 \mathrm{Btu} / \mathrm{hr}$ atau 1.090,75 kcal karena memiliki luas dan bagian yang lebih banyak dari beban transmisi lainnya.

Hasil penelitian yang diperoleh di dukung oleh penelitian yang dilakukan Ridhuan 2013 tentang “ Analisis Kebutuhan Beban Pendingin dan Daya Alat Pendingin AC untuk Aula Kampus 2 UM Metro" hasil penelitiannya adalah beban pendingin di pengaruhi oleh beberapa faktor yaitu beban pendinginan luar berupa panas melalui dinding, kaca, pintu atap dan lantai ruangan. Faktor yang cukup besar pengaruhnya yaitu pada dinding ruangan sebelah timur karena terkena sinar matahari langsung. Sedangkan untuk beban pendinginan dalam yaitu beban penghuni, komputer, lampu dan LCD. Faktor yang cukup besar yaitu orang, karena setiap orang akan mengeluarkan panas, semakin banyak orang maka akan semakin banyak panas yang dikeluarkan. Sehingga untuk ruang aula yang berukuran panjang 19,85 $\mathrm{m}$ dan lebar 7,85 $\mathrm{m}$ diperlukan kapasitas AC sebesar 8,6 PK yaitu sebesar 77.400 Btu/hr atau $19.350 \mathrm{kcal}$.

Selanjutnya penelitian yang dilakukan Syahrizal 2013 tentang "Analisis Konsumsi Energi Listrik Pada Sistem Pengkondisian Udara Berdasarkan Variasi Kondisi Ruangan" hasil penelitiannya adalah makin besar beban pendingin di dalam suatu ruangan, maka makin banyak kalor yang harus diserap oleh evaporator, dengan demikian kerja kompresor untuk mensirkulasikan refrigeran ke sistem AC akan semakin berat sehingga energi listrik yang dikonsumsi akan semakin banyak.

\section{KESIMPULAN DAN SARAN}

Berdasarkan hasil penelitian dan pembahasan maka dapat ditarik simpulan sebagai berikut: Proses perpindahan panas yang tejadi pada luas ruangan $58,575 \mathrm{~m}^{2}$ atau $630,501 \mathrm{ft}^{2}$ yaitu secara radiasi dan konduksi melalui beban ruangan, sehingga di peroleh nilai beban total kalor sebesar $34.979 \mathrm{Btu} / \mathrm{hr}$ atau 8.744,75 kcal. Beban kalor sangat mempengaruhi kinerja air conditioner (AC) dalam menghasilkan suhu nyaman dalam ruangan, seperti pada ruang rapat $\mathrm{BNN}$ Provinsi SULTRA menggunakan kapasitas AC 2 PK dengan beban pendingin total sebesar $34.979 \mathrm{Btu} / \mathrm{hr}$ atau 8.744,75 kcal, sehingga harus melakukan penambahan AC dengan kapasitas minimal 2 PK untuk memperoleh nilai kalor yang dapat dipindahkan AC $\left(Q_{1}\right)$ lebih besar dari beban kalor yang dihasilkan ruangan $\left(\mathrm{Q}_{2}\right)$ yaitu $36.000 \mathrm{Btu} / \mathrm{hr}>34.979 \mathrm{Btu} / \mathrm{hr}$ atau $9.000 \mathrm{kcal}>8.744,75 \mathrm{kcal}$ sehingga akan diperoleh kondisi yang nyaman.

\section{SARAN}

Saran yang dapat kami berikan sehubungan dengan penelitian yang dilakukan sebagai berikut: Peneliti selanjutnya untuk melakukan perhitungan beban pendingin pada bangunan atau kantor yang memiliki bagian peneduh. Lokasi penelitian diharapkan untuk menambah unit AC dengan kapasitas minimal 2 PK.. Ruangan yang akan menggunakan sistem pengkondisian udara harus terlebih dahulu memperhitungkan beban panas atau kalor yang dapat dipindahkan $\mathrm{AC}$ dan beban pendingin total dari ruangan.

\section{DAFTAR PUSTAKA}

Alfons E.P,.dkk, 2013, 'Analisis Pengaruh Variasi Massa LPG sebagai Refrigeran Terhadap Prestasi Kerja dari Lemari Es', Jurnal ROTOR Vol.6 Nomor, Januari 2013, Kalimantan, Universitas Jember.

ASHRAE, 1997, 'Handbook of Fundamentals'.

ASHRAE, 2001, 'Cooling Load Calculations and Principles'.

ASHRAE, 2016, 'Handbook HVAC Systems and Equipment'.

Astu Pudjanarso, dan Jati Nursuhud, 2008, 'Mesin Konversi Energi Edisi Revisi', Yogyakarta, CV Andi Offset.

Carrier, 1965, 'Handbook of air Conditioning System Design', New York, McGraw-Hill Book Company.

Fraim, David, Simamora.,dkk, 2014, 'Analisis Efektivitas Radiator Pada Mesin Toyota Kijang Tipe 5 K', Jurnal Online Poros Teknik Mesin Volume 4 Nomor 2, Manado, Jurusan Teknik Mesin Universitas Sam Ratulangi, hh. 140-141. DOI : jptmesin150266.

Harahap, Sabaruddin.,dkk, 2014, 'Perhitungan Ulang Beban Pendinginan Pada Ruang Auditorium Gedung Manggala Wanabakti Blok III Kementerian Kehutanan Jakarta', SINERGI Vol. 18, No. 3, Oktober 2014, Jakarta, Universitas Mercu Buana, hh. 150-151. DOI : $10.224 /$ sinergi.

Joto, R, 2013, 'Studi Perbandingan Pemakaianenergi Air Conditioner Inverter Dengan Air Conditioner 
Konvensional', ELTEK , hh.110-121. DOI : http://eltek.polinema.ac.id.index.php /eltek/article/view/9.

Muhammad, Zein, 2019, 'Analisa Sistem Pendingin Untuk Kenyamanan Ruangan Pada Industri Garmen', Jurnal Teknik Mesin Ubl, Vol.6 No.2, Lampung, Universitas Bandar Lampung.

Priyadi, Irnanda, 2009, 'Optimasi Penggunaan Ac Sebagai Alat Pendingin Ruangan', Jurnal llmiah Bidang Sains Teknologi Murni Disiplin dan Antar Disiplin. Vol II. No. 6, September 2009, Bengkulu, Jurusan Teknik Elektro, Fakultas Teknik, Universitas Bengkulu, hh. 47-49. DOI : http://respository.unib.ac.id/id/eprint/7354.

Ridhuan, Kemas dan Andi, Rifai, 2013, 'Analisa Kebutuhan Beban Pendingin dan Daya Alat Pendingin Ac Untuk Aula Kampus 2 Um Metro', TURBO ISSN 2301-6663 Vol. 2 N0. 2, Lampung, Universitas Muhammadiyah Metro, hh. 12. DOI : http:// dx.doi.org/10.24127/trb.v2i2.26.

Subedjo, Slamet,.dkk, 2011, 'Analisa Variasi Beban Pendingin Udara Kapasitas 1 PK pada Ruang Instalasi Uji dengan Pembebanan Lampu', Tegal, Universitas Pancasakti.
Suhendar, dkk, (2013), 'Audit Sistem Pencahayaan dan Sistem Pendingin Ruangan di Gedung Rumah Sakit Uum Daerah (RSUD) Cilegon', Cilegon, SETRUM , II, hh. 21-27.

DOI : http://dx.doi.org/10.60553/setrum.v2i2.486.

Susanto, Arief,. dkk, 2017, 'Analisis Kebutuhan Beban

Pendingin Dengan Metode Cooling Load Temperature Difference (Cltd) Pada Ruang Lobby Gedung Simulator Sekolah Tinggi Penerbangan Indonesia', Jurnal Ilmiah Aviasi Langit Biru Vol. 10 No.3 Oktober 2017, Tangerang, Sekolah Tinggi Penerbangan Indonesia Curug. Hh. 32-35. DOI : http://journal.ppicurug.ac.id/index.php/jurnal-langitbiru/article/view/223.

Standar Nasional Indonesia, 2011, 'Tabel Konduktivitas Termal', SNI-03-6389-2011 ISO 83362009 Edisi 2.

Syahrizal, Iman,. dkk, 2013, 'Analisis Konsumsi Energi Listrik Pada Sistem Pengkondisian Udara Berdasarkan Variasi Kondisi Ruangan', Jurnal ELKHA Vol.5, No 1, Maret 2013, Pontianak, Universitas Tanjungpura. DOI : http://dx.doi.org/10.26418/elkha.v5i1.3002.

Yunus A, Cengel, 1997, 'Thermodynamics and Heat Transfer', Mc. Graw Hill, America. 